Dr. sc. Ratko Brnabić, docent

Pravni fakultet Sveučilišta u Splitu

\title{
IZMJENA ODREDABA UGOVORA O ISKORIŠTAVANJU UGLJIKOVODIKA
}

\author{
UDK: $347: 620.9$ \\ Pregledni znanstveni rad \\ Primljeno: 25. 01. 2016.
}

\begin{abstract}
Seizmografska istraživanja čiji je naručitelj Vlada Republike Hrvatske ukazuju na to da jadransko podmorje sadrži zalihe ugljikovodika. Iako tu nije riječ o posebice bogatim zalihama, rezultati tih početnih istraživanja pobuđuju interes multinacionalnih trgovačkih društava koja se bave preradom ugljikovodika. Pravna sigurnost gospodarskog pothvata tim društvima jedna je od najvažnijih pretpostavki za ulaganje. Taj zahtjev će se ispuniti s(p)retnom i umješnom kombinacijom zakonodavnog uređenja tog gospodarskog područja države domaćina s jedne strane te sklapanjem posebnih „tailor made“ ugovora s druge, što predstavlja veliki izazov za ugovorne strane. Naime, ugovori o iskorištavanju ugljikovodika moraju kao i svaki drugi ugovor biti odraz svih načela obveznog prava pa je u tom smislu potrebno pronaći pravu ravnotežu između načela ravnopravnosti ugovornih strana i načela pacta sunt servanda, ali i zahtjeva inozemnog trgovačkog društva koje ulaže znatna sredstva u pothvat i očekuje određene povlastice koje će omogućiti razmjerno brz povrat barem početno uloženih sredstava. Ne smije se zaboraviti da je tu riječ o višegodišnjim ugovorima koji trebaju izdržati test ponekad burnih gospodarskih ali i društveno-političkih promjena te treba utvrditi jesu li se okolnosti toliko promijenile da je za jednu od ugovornih strana ispunjenje ugovornih obveza otežano ili se više ne može ostvariti niti svrha ugovora. Kod spomenutih ugovora, raskid ugovora najčešće nije u interesu ugovornih strana. U radu se provodi raščlamba najvažnijih odredaba tih ugovora te se predlažu rješenja koja bi tim pravnim poslovima dala potrebnu razinu prilagodljivosti svim gospodarsko-političkim promjenama koje će sigurno nastati.
\end{abstract}

\section{Ključne riječi: Ugovori u svezi s iskorištavanjem ugljikovodika, Joint venture, Koncesija, Povreda ugovora, Pregovori}

\section{UVOD}

Izmjena pojedinih odredaba već sklopljenih ugovora o iskorištavanju ugljikovodika jedno je od vitalnih pitanja za gospodarstvo države. Vlade države domaćina nerijetko smatraju da ugovorne odredbe treba izmijeniti ili staviti izvan snage jer je tu po prirodi stvari riječ o višegodišnjim ugovorima koji su odraz odnosa snaga pregovarača i njihovih mogućnosti u vrijeme sklapanja ugovora. Država domaćin želi zadržati suverena prava ${ }^{1}$ nad vlastitim neobnovljivim

1 Treba razlikovati pojam suverenosti od pojma suverenih prava. Obalna država ostvaruje nad epikontinentalnim pojasom suverena prava radi njegova istraživanja i iskorištavanja njegovih prirodnih bogatstava. Prava obalne države isključiva su u tom smislu da, ako obalna država ne istražuje epikontinentalni pojas ili ne iskorištava njegova prirodna bogatstva, nitko ne može poduzeti te djelatnosti bez izričitog pristanka obalne države. Prava obalne države na epikontinentalni pojas ne ovise o stvarnoj ili fiktivnoj okupaciji, niti o bilo kakvom izričitom proglasu (za razliku od isključivog gospodarskog 
izvorima energije u epikontinentalnom pojasu. Ta nastojanja su upravo suprotna interesima multinacionalnih trgovačkih društava čija je glavna djelatnost iskorištavanje (prerada i proizvodnja) ugljikovodika. Ta društva su najčešće povezana u koncerne, a nerijetko su s državom ugovor sklopile onda kada su imala dobar pregovarački položaj pa se tako stečenih prava iz ugovora nisu spremna odreći „,bez borbe“ pri čemu im je glavni argument pozivanje na načelo o obvezi ispunjenja preuzetih ugovornih obveza - pacta sunt servanda. U praksi se koriste ugovori o koncesiji, ugovori o podjeli proizvedenog energenta, ugovori o uslugama i/ili ugovori o zajedničkom pothvatu. U nastavku ovog rada za ta društva koristit ćemo izraz ulagač pri čemu valja naglasiti da ulagač i država ugovornica na različite načine mogu urediti svoje pravne odnose pa s pojmom društva koje je ulagač ne treba miješati pojam trgovačkog društva koje su osnovali država i ulagač radi lakšeg upravljanja gospodarskim pothvatom. ${ }^{2} \mathrm{~S}$ druge strane, država ugovornica zahtjev za izmjenom pojedinih ugovornih odredaba temelji na pravu pobijanja onih ugovornih odredaba koje su izraz nejednakosti ugovornih strana te na klauzuli o promijenjenim okolnostima (clausula rebus sic stantibus) ${ }^{3}$. Ipak iz prakse odlučivanja arbitražnih tijela, a posebice iz obrazloženja njihovih odluka, može se zaključiti da se u slučaju spora maksimalno štite interesi inozemnih ulagača. ${ }^{4}$

\section{OPĆA PITANJA U SVEZI S IZMJENOM UGOVORA}

Ako se na trenutak izvan rasprave stavi dvojbeno pitanje nacionalizacije državnih prirodnih neobnovljivih resursa energije, već je po prirodi stvari dostatno složeno pitanje prava države da jednostrano izmijeni pojedine odredbe tih ugovora, da otvori pregovore ${ }^{5}$ o izmjeni odredaba a posebice prava države da zakonodavnim intervencijama i različitim fiskalnim mjerama utječe na pravni

pojasa koji obalna država mora proglasiti). Prirodna bogatstva na koja obalna država polaže suverena prava obuhvaćaju rudno i drugo neživo bogatstvo morskog dna i podzemlja kao i živa bića koja pripadaju vrstama od dna, tj. bića koja su u stadiju u kojem se mogu loviti bilo nepomična na morskom dnu ili ispod njega ili se ne mogu pomicati ako nisu u stalnom fizičkom dodiru s morskim dnom ili podzemljem. Država može disponirati svojim suverenim pravima u epikontinentalnom pojasu ugovorima o iskorištavanju ugljikovodika.

2 Vukmir, B., Ugovori o zajedničkim ulaganjima, Informator, Zagreb, 1994., str. 27-43.

3 Mato, H. T., „The Role of Stability and Renegotiation in Transnational Petroleum Agreements“, Journal of Politics and Law, Vol. 5, 1 (2012.), str. 33-43, str. 35. Također vidi odluku Visokog Trgovačkog suda RH: Ako se nakon sklapanja ugovora promijene okolnosti zbog kojih je otežano ispunjenje ugovorne obveze jedne stranke ili zbog kojih ona ne može ostvariti svrhu ugovora, ta stranka može putem suda, konstitutivnim tužbenim zahtjevom, zahtijevati da se ugovor raskine, ali ne može tražiti da se pojedine ugovorne odredbe izmijene budući da izmjena ugovora ovisi i o volji druge ugovorne stranke. Odluka Visokog Trgovačkog suda RH, br. Pž-2815/07 od 27. travnja 2010.

4 Cantegreil, J., „The Audacity of the Texaco/Calasiatic Award: René-Jean Dupuy and the Internationalization of Foreign Investment Law“, European Journal of International Law, Vol. 22, br. 2, str. 443. i dalje.

5 Valja naglasiti da je tu riječ o otvaranju novih pregovora a ne o nastavku onih pregovora koji su prethodili sklapanju prvobitne verzije ugovora. 
položaj ugovornih strana a time i na isplativost gospodarskog pothvata. ${ }^{6}$ Glavno sredstvo kojim su se mnoge države koristile u prošlosti jest nacionalizacija cijelog gospodarskog pothvata koji za cilj ima iskorištavanje i preradu neobnovljivih izvora energije a posebice ugljikovodika. Načelo nacionalnog suvereniteta uključuje pravo države da zahtijeva ponovno pregovaranje o odredbama važećih ugovora, a ne i pravo da odmah nacionalizira, tj. izravno preuzme takve pothvate uz isključenje inozemnog ulagača.

Najčešći razlozi zbog kojih je potrebno ponovno pregovarati jesu sljedeći:

1) Ako su odredbe ugovora stroge, kogentne, ugovor je sklopljen na dulje vrijeme te je unesena stabilizacijska klauzula ${ }^{7}$ prema kojoj izmjene propisa ne utječu na ugovor;

2) Kada je iz ugovora posve jasno da je u vrijeme njegova sklapanja ulagač (inozemno trgovačko društvo) imao znatno jači pregovarački položaj;

3) Ako su se od sklapanja ugovora okolnosti u tolikoj mjeri izmijenile da ga je nužno uskladiti s postojećim stanjem jer je ispunjenje ugovora za jednu ugovornu stranu otežano ili ona više ne može ostvariti svrhu ugovora;

4) Kada ugovor prema svom sadržaju praktički onemogućava državu ugovornicu da spomenute izvore energije koristi kao zamašnjak svog gospodarskog razvoja.

Ugovor o ulaganju u gospodarski pothvat iskorištavanja ugljikovodika morao bi sadržavati odredbe koje se tiču mogućnosti ponovnog pregovaranja, periodične revizije, usklađivanja prema trenutnim tržišnim okolnostima te druge odredbe koje uzimaju u obzir dinamiku razvoja te gospodarske grane. Takvim odredbama postiže se potrebna mjera prilagodljivosti u ugovorni režim iskorištavanja ugljikovodika, a tu je riječ o rješenjima koja su prihvatljiva za obje ugovorne strane jer dugoročno niti ulagaču ne odgovara stanje da je kvalitetno zaštićen ugovorom, ali ta nemogućnost izmjene pojedinih odredaba izaziva veliko nezadovoljstvo kod vlade države ugovornice i njezinih građana. To pitanje posebice dobiva na značaju ako je ugovor sklopila jedna vlada koju je sastavila jedna politička opcija, a negativne posljedice trpi nova vlada što onda može imati nepredvidljive gospodarske ali i društveno-političke učinke pa i dovesti do pada vlade. Prilagodljivost ugovora smanjuje rizik jednostranog kršenja ugovornih obveza.

Brojni su razlozi koji govore u prilog pristupu da ugovor mora biti prilagodljiv. Prvo, ako je ugovor uređen da bude prilagodljiv tada se neizbježni zahtjevi za ponovnim pregovaranjem usmjeravaju u unaprijed uređeni postupak njegove izmjene pa se time izbjegavaju sporovi i s njima povezani nepotrebni troškovi koji će neminovno nastati ako ne postoji razrađeni postupak za takve slučajeve. Drugo, takvim ugovorom mogu se urediti pretpostavke za postupak postupnog

6 Böckstiegel, K., Der Staat als Vertragspartner Ausländischer Privatunternehmen, Athenäum-Verl., Frankfurt a.M./ Bonn, 1971., str. 145.

7 O tim klauzulama detaljnije kod Faruque, A., „Validity and Efficacy of Stabilisation Clauses“, Journal of International Arbitration, Vol. 23, 4 (2006.), str. 317-336. 
preuzimanja gospodarskog pothvata iskorištavanja ugljikovodika od strane države ugovornice a sve prema ranije ugovorenim postupovnim pravilima pri čemu bi se postupak preuzimanja provodio u fazama i pratio bi gospodarski razvoj države domaćina te sposobnost države da uspješno obavlja upravljačke i poslovodstvene funkcije u pothvatu (marketing, financiranje, upravljanje). Treće, okolnost da je ugovor prilagodljiv sprečava rizik nastanka negativnih posljedica koje za državu nastaju provede li se nacionalizacija: negativni marketinški učinci, problemi s financiranjem koje se mora preuzeti odmah i to u cijelosti, nesklonost novih ulagača za sudjelovanjem u pothvatu, obveza plaćanja visokog iznosa naknade štete. Četvrto, prilagodljivost ugovora otvara ugovornim stranama mogućnost da primijene novi način ugovaranja ili općenito uvedu novi način uređenja međusobnih prava i obveza u konkretnoj grani gospodarstva kao što se pokazalo u svezi s proizvodnjom i preradom ugljikovodika. Iz svega navedenoga vidljivo je da će se prije ili kasnije pojaviti potreba za revizijom dugogodišnjih ugovora kojima se uređuje iskorištavanje ugljikovodika.

\subsection{Pravna polazišta o pitanju izmjene ugovora}

Praksa ponovnog pregovaranja o izmjeni važećih, pravno obvezujućih ugovora obilježena je brojnim dvojbama i pravnim pitanjima koja je potrebno riješiti. Ima li država pravo na jednostranu izmjenu odredaba ugovora koji je sklopila s ulagačem? Brojni autori, posebice oni koji dolaze iz razvijenih država čija trgovačka društva u pravilu nastupaju kao ulagači na inozemnim tržištima, ističu važnost poštovanja načela nepovredivosti ugovora i dužnosti ugovornih strana da ispune svoje ugovorne obveze (,,pacta sunt servanda“) jer smatraju da spomenuta načela imaju prednost pred svim ostalim načelima. ${ }^{8}$

Zauzme li se, rasprave radi, polazište da se na ugovor primjenjuje domaće pravo države ugovornice, tada se ugovorne strane ne mogu pozivati na načela međunarodnog prava. Pitanje izmjene pojedinih odredaba leži isključivo unutar

8 To se polazište i dalje razrađuje pa se ono tumači tako da je nepovredivost ugovora zajamčena ako je za slučaj spora ugovorena nadležnost međunarodnog arbitražnog sudišta-tijela dakle sudišta koje nije nacionalnog karaktera te ako je u ugovor ugrađena tzv. stabilizacijska klauzula. Tradicionalna i najjednostavnija stabilizacijska klauzula ponešto je skrivena, zamaskirana u odredbi o „konzistentnosti“ kao što je odredba: „Ovaj sporazum (ugovor) ima punu pravnu snagu i učinke zakona Liberije i kao takav, zajedno sa svim liberijskim zakonima opće primjene koji nisu suprotni ili neusklađeni s izričitim odredbama ovog ugovora, uređuju prava i obveze ugovornih strana“. U afričkim zemljama francuskog utjecaja stabilizacijska klauzula strogo zabranjuje naknadnu izmjenu poreznih propisa koji utječu (ili mogu utjecati) na gospodarski pothvat. Navodi se da za vrijeme trajanja pothvata moraju ostati nepromijenjene porezne stope te općenito propisi koji uređuju oporezivi prihod za razdoblje od 30 godina od trenutka kada je započela komercijalna eksploatacija. Drugi primjer stabilizacijske odredbe jest i sljedeća odredba: Povredu ovog ugovora predstavlja stupanje na snagu izmjena postojećih zakona kao i donošenje novih zakona koji se odnose na društvo ulagača ili njegove dioničare. To će posebice biti u slučaju kada spomenute izmjene postojećih propisa negativno utječu tj. umanjuju netto dobit odnosno financijski položaj ulagača ili njegovih dioničara. Tako je iz arbitražne odluke u predmetu Texaco protiv Republike Libije vidljivo da, iako se takvim odredbama ulagača štiti od pune nacionalizacije, iz obrazloženja se može lako zaključiti da se zaštita pruža i u slučaju kada država domaćin poziva na izmjenu pojedinih odredaba ugovora. Predmet Texaco Overseas Petroleum Company v. The Government of the Libyan Arab Republic dostupan na http://www.trans-lex.org/261700, pregledano 15. 10. 2015. 
jurisdikcije pravnog sustava države domaćina. U okvirima međunarodnog prava jedino se raspravlja o tome je li u konkretnom slučaju riječ o prikrivenoj nacionalizaciji tih izvora energije što je temelj odgovornosti za štetu koja je nastala ulagaču (tzv. ,šuljajuća, puzeća nacionalizacija“). ${ }^{9}$

S druge strane, zauzme li se polazište da to pitanje spada u područje međunarodnoga prava, potrebno je pronaći načela, pravila međunarodnog prava koja su primjenjiva na ugovore između države koja ima energetske resurse i ulagača koji je po prirodi stvari osoba privatnoga prava. Klauzula promijenjenih okolnosti koju poznaje i međunarodno pravo može biti temelj za izmjenu pa čak i raskid ugovora ako su se izmijenile bitne okolnosti na kojima se temeljio taj ugovor. ${ }^{10}$ Treba spomenuti da su se pravom na jednostrani raskid ugovora nerijetko koristili i ulagači ako im je prema ugovoru pripadalo to pravo.

Zbog sve većeg broja takvih sporova te ozbiljnih učinaka koji iz njih proizlaze za gospodarstvo države, ali i za njezine međunarodne političke odnose, nužno je razviti pravila za njihovo rješavanje. Sporovi najčešće nastaju zbog neispunjenja ugovornih obveza, zbog neprimjereno dugog roka važenja ugovora ili ako je vidljivo da ulagač ima znatno povoljniji položaj u ugovornom odnosu što znači da je iskoristio svoju pregovaračku moć. Ponekad ulagači imaju povoljniji položaj jer su državu ugovornicu zastupali neiskusni ili nedostatno stručni pregovarači. ${ }^{11}$ Uzevši u obzir sve te okolnosti, pravo ugovornih strana na otvaranje novih pregovora o izmjeni pojedine odredbe ugovora ne bi bilo dobro onemogućiti uvođenjem ranije spomenute stabilizacijske klauzule. Stoga uopće nije moguće zamisliti slučaj da bi ugovor o iskorištavanju ugljikovodika bio apsolutno nepromjenjiv jer će se s vremenom promijeniti okolnosti koje su temelj tog ugovora. Takvi ugovori se po prirodi stvari sklapaju na dulje razdoblje i uključuju brojne rizike pa je jasno da treba pravno urediti mehanizme za izmjenu pojedinih odredaba. Nadalje, promatrajući širu sliku, takav ugovor mora biti prilagodljiv da bi omogućio gospodarski rast države domaćina te se ne smije dogoditi da ta država ne dobije dostatne količine energenta za svoje potrebe. Mogućnost izmjene ugovora čak može biti i u interesu ulagača jer bi izmjene ugovora mogle ubrzati političke promjene koje će rezultirati stvaranjem povoljnog pravno-ekonomskog okružja za inozemna ulaganja.

\subsection{Poslovna praksa i običaji u svezi s novim pregovorima}

Iako na prvi pogled ne bi trebalo biti tako, nije uvijek jednostavno razlikovati postupak izmjene pojedinih odredaba ugovora od postupka nacionalizacije

9 Detaljnije o tome vidi kod Humphreys, M., Sachs, J. D., Stiglitz, J. E. (Ur.), Escaping the Resource Curse, Columbia University press, New York, 2007., str. 110. Također vidi Wellhausen, R. L., The Shield of Nationality, Cambridge University Press, 2014., str. 26.

10 O tome detaljnije vidi Geiger, R., ,The Unilateral Change of Economic Development Agreements“, International and Comparative Law Quarterly, Vol. 23, 1 (1974.), str. 73-104.

11 Oon, K. C., The Politics of Oil in Indonesia: Foreign Company-Host Government Relations,

Cambridge University Press, 1986., str. 201. 
cijelog pothvata iskorištavanja ugljikovodika. To će posebno biti slučaj kada država domaćin, koristeći sada svoj povoljniji pregovarački položaj (jer je primjerice ulagač već izgradio postrojenja pa se ne može olako povući), prisili ulagača da prihvati potpuno ili djelomično preuzimanje pothvata od strane države ili da prihvati nastavak poslovanja pod znatno izmijenjenim, nepovoljnijim uvjetima. Ponekad će se postupak nacionalizacije od postupka izmjene pojedinih odredaba ugovora razlikovati samo u nijansama. Jedna strana uporabila je svoju pregovaračku snagu ako nametne nove, za njih povoljnije uvjete poslovanja, a važeći ugovor utemeljen je na ranijim ulaganjima koja su provedena pod drugačijim uvjetima. Kod ponovnog pregovaranja, riječ je o tome da su odredbe o kojima se raspravlja već ugrađene u ugovor pa se može zaključiti da postoji kontinuitet u ostvarivanju ciljeva gospodarskog pothvata. Raščlamba ostvarenih izmjena tih ugovora rijetko je predmet dubljih znanstvenih rasprava jer se pregovori i izmjene provode praktički u tajnosti, a same izmjene su na prvi pogled neznatne. Revizija ugovora često se preklapa, tj. koindicira sa stupanjem na snagu novih poreznih propisa te propisa o inozemnim ulaganjima države domaćina. Načelno, postupak revizije pojedinih odredaba ugovora, u kombinaciji s postupnim preuzimanjem pothvata, ima prednost pred postupkom izravne nacionalizacije prirodnih resursa od strane države domaćina. Praksa ukazuje na zaključak da je najveći broj tih ugovora izmijenjen, a u samo malom broju slučajeva provela se nacionalizacija tih gospodarskih pothvata iskorištavanja ugljikovodika. ${ }^{12}$ Postupak ponovnog pregovaranja ima prednost pred nacionalizacijom jer se time izbjegavaju brojni problemi koji se pojavljuju onda kada se provodi postupak nacionalizacije. Stoga čak ako i izuzmemo raspravu o obvezi naknade nastale štete ulagaču, već dovoljan problem predstavlja pitanje upravljanja projektom, širenje postojećih kapaciteta, marketing i financiranje projekta. U praksi se pokazalo da ako je ugovorom država stekla poslovne udjele u društvu - nositelju pothvata, a ti udjeli joj osiguravaju sudjelovanje u odlučivanju i stupanj kontrole, nadzora, veće su šanse da će takav ugovor opstati. Dugoročno se pokazalo da kod takvih ugovora najveću postojanost pokazuju one odredbe prema kojima ulagač osigurava plasman proizvoda, opskrbu pothvata potrebnom tehničkom opremom te pruža tehničku podršku u najširem smislu te riječi.

U svezi s iskorištavanjem ugljikovodika, glavna pitanja o kojima treba povesti računa jesu opseg i sadržaj obveza države ugovornice te njezin udio u pothvatu, pitanje višestrukog porasta cijena proizvoda, iznos koncesijske naknade (fiksni i varijabilni dio), visina poreznih stopa, pitanje rabata kod prodaje, mogućnost naknadnog uvođenja posebnih poreza na dobit. Nadalje, treba riješiti pitanje postoji li obveza ulagača da zapošljava domaću radnu snagu te u kojem dijelu pothvata oni rade (opskrba, servis, proizvodnja, marketing). U novije vrijeme takvi ugovori sadrže izričitu odredbu da se na njih primjenjuju nacionalni propisi

12 Tako Hawkins, R., Government Takeovers of U.S. Foreign Affiliates, Int'1 Bus 5 (1975.), str. 10. Također vidi Prahalad, K., Lieberthal, K., The End of Corporate Imperialism, Harvard Business Review Classics, 2008., str. 110. 
države domaćina, čime se izbjegava mogućnost da takav ugovor predstavlja svojevrsnu ,pravnu enklavu“ u nacionalnom pravnom sustavu. Sklapaju se vrlo detaljno uređeni ugovori koji sadrže razrađene pravne mehanizme za slučaj kada je potrebno izmijeniti pojedine odredbe. Takvi sigurnosni mehanizmi ugrađuju se ne samo u ugovore o iskorištavanju ugljikovodika, već postoje u svim gospodarskim granama jer uvijek postoji rizik zbog fluktuacije cijene roba na tržištu.

U svezi s pregovorima, postavlja se pitanje imaju li načela dobrog upravljanja i vladavine prava ikakav značaj kod cikličkih promjena na tržištu gospodarskog iskorištavanja ugljikovodika. Svjedoci smo trenda učestalih promjena cijena ugljikovodika pa su vlade država proizvođača neprestano uključene u izmjene temeljnih odredaba pod kojima su ti ugovori sklopljeni. Te izmjene su predmet rasprave u slučajevima kada su prve verzije ugovora sklapane u razdobljima kada je cijena proizvoda od ugljikovodika bila razmjerno niska (npr. od 1985. do1999.). Također do zahtjeva za izmjenom ugovora dolazi i u slučaju znatnih političkih promjena kada nova vlada države ugovornice ima drugačije stavove prema inozemnim i općenito privatnim ulaganjima, a također u slučajevima kada vlada države nakon početnog vala privatizacije trgovačkih društava pokušavaju provesti obrnuti postupak: nacionalizaciju trgovačkih društava. Ti problemi nastat će kada se ugovorom o iskorištavanju ugljikovodika nije uredila mogućnost njegove automatske izmjene u slučaju kada se ispune točno određene pretpostavke. Pokazalo se u praksi da nije dostatno ako ugovor sadrži odredbe o izmjeni visine iznosa naknade koju ulagač plaća prema dobiti koja se ostvaruje pothvatom jer je ugovor najčešće izraz nejednakog pregovaračkog položaja ugovornih strana. Ugovori koje su sklapale neiskusne vlade država nastalih raspadom SSSR-a često su sadržavali odredbe koje idu u korist inozemnog ulagača. Tada bi se pokazalo da te države imaju nevelike prihode od svojih rezerva ugljikovodika iako je tržišna cijena tih proizvoda u međuvremenu višestruko porasla. ${ }^{13}$ Kako raste tržišna cijena proizvoda, redovito će se postaviti pitanje nisu li nastupile promijenjene okolnosti zbog kojih bi država ugovornica imala pravo na raskid ili izmjenu ugovora. ${ }^{14} \mathrm{U}$ takvim slučajevima prisutna je opasnost da tu više nije riječ o dvostrano obvezujućim ugovorima već o „okvirnim političkim sporazumima“. Takvo polazište bi se u određenim okolnostima moglo i prihvatiti, ali se pritom ne smije zanemariti važna okolnost: inozemni ulagač u projekt ulaže znatna sredstva koja će vratiti tek nakon duljeg vremena. Ako država jednostrano mijenja pravila igre izmjenama propisa (posebice poreznih propisa), tada se narušava ravnoteža između ugovornih strana. Kako bi se izbjegao slučaj da inozemni partner-ulagač postane ,talac“ države domaćina, ugovorom se moraju predvidjeti zaštitna sredstva koja ulagaču pomažu da održi relativnu ravnotežu. U ta sredstva

13 Primjerice, ako se ugovori da ulagač ima pravo povrata troškova nastalih u fazama ispitivanja i istraživanja što im se mora isplatiti iz dobiti koju ostvaruje pothvat. Detaljnije o tome vidi kod Wälde, T., „Managing the Risk of Sanctions in the Global Oil \& Gas Industry: Corporate Response Under Political, Legal and Commercial Pressures“, Texas International Law Journal, Vol. 36, 1 (2005.), str. 183. i dalje.

14 Neki autori zauzimaju polazište da zahtjev države za ostvarenje suverenih prava ima prednost $\mathrm{u}$ odnosu na interese inozemnog ulagača. O tome detaljnije vidi primjerice Sornarajah, D. M., The International Law on Foreign Investment, Cambridge, 2004., str. 84. i 119. 
spadaju odredbe o primjeni prava međunarodnih ulaganja, polazište o nužnosti internacionalizacije prava koje se primjenjuje na ugovor, unošenje u ugovor klauzule o stabilizaciji odredaba, klauzule o nadležnosti međunarodne arbitraže te odredba kojom se izravno određuje arbitražno tijelo koje će odlučivati u slučaju spora. Primjena načela „vladavine prava“ ima za cilj preoblikovanje tih pravnih poslova iz političkih sporazuma u ugovore koji se provode prema pravnim normama i provedbenim, postupovnim odredbama međunarodnog značaja što doprinosi pravnoj sigurnosti ulaganja. ${ }^{15}$

Raniji ugovori o iskorištavanju energetskih resursa između ulagača i država Srednjeg istoka nerijetko su sklapani na razdoblje od 99 godina. ${ }^{16} \mathrm{~S}$ vremenom su se prilike na svjetskom tržištu izmijenile, i to u korist ulagača, pa su takvi pravni poslovi postali gotovo štetni za države domaćine. Već se tada zaključilo kako ih je potrebno izmijeniti i time omogućiti kontinuitet ostvarenja gospodarskog cilja uz istovremeno izbjegavanje slučajeva da država domaćin poduzme radikalne pravne mjere. U novije vrijeme ugovori o iskorištavanju ugljikovodika sklapaju se na razdoblje od 25 do 35 godina, ovisno o tome računa li se kao početak datum sklapanja ugovora ili datum početka komercijalne proizvodnje, a u praksi je bilo slučajeva da su takvu ugovori i znatno kraćeg trajanja. Te razlike proizlaze iz toga što je kod iskorištavanja ugljikovodika relativno kraće razdoblje od početka istraživanja do trenutka kada se početno ulaganje isplatilo kroz proizvodnju. Uputno je da država domaćin ugovorom razradi vremenski slijed za istražne radnje, izradu studije o isplativosti, izgradnje te proizvodnje jer će u suprotnome ulagač sklapanjem ugovora praktički samo „rezervirati, pridržati“ svoje pravo na izvor da bi isključio konkurenciju, a neće se žuriti s provedbom pothvata. Države će, s druge strane, nastojati da ugovor bude što kraćeg trajanja jer se zalihe ugljikovodika na tom nalazištu još neće iscrpiti pa se za nastavak mogu ugovoriti povoljniji uvjeti, dok će ulagači nastojati ugovoriti da razdoblje trajanja ugovora bude dostatno za iscrpljivanje cjelokupnih zaliha nalazišta. ${ }^{17}$

\section{UGOVORNA I ZAKONSKA SREDSTVA ZA IZMJENU UGOVORA}

Zbog duljine trajanja ugovora u kojem je poslovni rizik već bio neravnomjerno raspoređen među ugovornim stranama te činjenice da u međuvremenu mogu nastati i nepredviđene odnosno izmijenjene okolnosti, noviji ugovori te vrste

15 Ipak, država domaćin mora voditi računa o tome kakvu poruku svojim postupcima šalje drugim ulagačima. Detaljnije vidi Wälde, T. W., „Law, contract and reputation in international business: What works?“, Bus. Law Intl., 2 (2002.), str. 190. i dalje.

16 Prosječna duljina trajanja tih prvih ugovora bila je od pedeset do sedamdeset godina. Detaljnije o tome Fischer, P., Die Internationale Konzession, Springer, 1974., str. 400. Primjerice ugovor o koncesiji iz 1933. između trgovačkog društva A.R.A.M.C.O. i Saudijske Arabije sklopljen je na 60 godina. Ugovor između Kraljevine Katar i trgovačkog društva $A P O C$ iz 1935., sklopljen je na sedamdeset i pet godina. Ugovor između trgovačkog društva Firestone i Republike Liberije iz 1928., sklopljen je na devedeset i devet godina.

17 Detaljnije o novijoj praksi ugovoranja vidi kod Beredjick, N., Petroleum Investment Policies in Developing Countries, Springer, 1988., str. 231. i dalje. 
sadrže odredbe koje omogućavaju lakšu izmjenu ugovora. U rješavanju tog pitanja postoje tri polazišta. Prvo, mogu se sklopiti ugovori u kojima se relativno jasno definiraju okolnosti koje za posljedicu imaju obvezu ugovornih strana da ponovno pregovaraju (jedna od tih okolnosti redovito je protek vremena). Drugo, u nekim ugovorima određuje se da su, uz protek vremena, glavne pretpostavke za ponovno pregovaranje znatnija izmjena odredaba koje uređuju fiskalni sustav države ugovornice (visina poreza i koncesijske naknade, način njihova obračunavanja) ili znatna promjena cijena finalnog proizvoda na tržištu. Treće, ugovori kojima se uređuje da će tijekom vremena porezno opterećenje rasti po određenoj stopi te koji sadrže odredbe o dužnosti ulagača da napusti, odrekne se dijela koncesioniranog područja ispune li se određene pretpostavke pri čemu bi se postupak izmjene ugovora proveo gotovo automatski. Posebice će u ovom posljednjem slučaju doći do spora pa će ugovorne strane, raspravljajući o tome jesu li se ispunile ugovorene pretpostavke da ulagač napusti dio koncesioniranog područja, redovito otvoriti nove pregovore.

Do 70-ih godina prošlog stoljeća ugovori o iskorištavanju ugljikovodika u pravilu nisu sadržavali mehanizme za izmjenu odredaba ugovora putem ponovnog pregovaranja, ali od tada spomenute klauzule postaju redoviti sastojak tih ugovora. U tom smislu, ponekad će u ugovor biti ugrađena odredba o obvezi periodičnog pregovaranja ili će se, primjerice, ugovorom precizno definirati pretpostavke koje dovode do aktivacije klauzule o obvezi ponovnog pregovaranja. Ponekad će se ugovorom jasno urediti da se o pojedinim odredbama ponovno pregovara protekom određenog roka bez obzira na okolnosti. Ipak, najčešće se ugovorima predviđa da do ponovnih pregovora dolazi zbog promijenjenih okolnosti - clausula rebus sic stantibus. Ipak, kod ugovora o iskorištavanju ugljikovodika treba ograničiti opseg primjene spomenutog načela na način da se ono ne primjenjuje u svom najširem smislu. ${ }^{18}$

Uz spomenutu klauzulu, ugovor o iskorištavanju ugljikovodika redovito sadrži sljedeće sastojke. Prvo, sadrži precizan opis - definicije svih pretpostavki koje za posljedicu imaju dužnost ugovornih strana na ponovno pregovaranje. To će primjerice biti protek vremena od početka proizvodnje ili protek vremena od trenutka početnog ulaganja uvećano za razdoblje koje je potrebno za povrat početnog uloga. Tu valja uvrstiti i slučajeve kada je došlo do materijalne, konkretne promjene bitnih okolnosti, a te promjene su vidljive u istovrsnim ugovorima, međunarodnim propisima, promjenama cijena na svjetskom tržištu tih energenata, promjenama u vlasničkoj i upravljačkoj strukturi trgovačkog društva - ulagača, u zakonodavnim promjenama države domaćina te u slučaju kada ulagač ostvari znatan višak dobiti. Drugo, ugovorom se mora urediti i opseg pitanja o kojima se može odnosno mora ponovno pregovarati. Tako se može ostaviti otvorenim pravo na ponovno pregovaranje o svakoj točki ugovora ili pravo pregovaranja ograničiti samo na ključne odredbe kao što su odredbe o oporezivanju i fiskalnom režimu, o

18 Detaljnije vidi kod Girsberger, D., „Fundamental alteration of the contractual equilibrium under hardship exemption“, Jurisprudence, 19, 1 (2012.), str. 121. i dalje. 
određivanju cijena, politici zapošljavanja te o modalitetima postupka proizvodnje. Treće, treba urediti i pravne standarde koje će ugovorne strane primjenjivati kod ponovnih pregovora. Ugovorom se može uvesti u primjenu načelo pravednosti u svezi s ciljanom stopom povrata na uloženi iznos, a to načelo može se primijeniti i kod određivanja omjera sudjelovanja u troškovima (gubitku) i dobiti pothvata. Nadalje, trebaju se navesti rizici koje ulagač preuzima ili koje će preuzeti u budućnosti. Nadalje, moguće je sadržaj ugovora vezati za sadržaj usporedivih ugovora iste vrste koje su sklopili treći ili pak za propise o ulaganjima koji vrijede u razvijenoj državi istog pravnog kruga te porezne propise druge države koji su primjenjivi na konkretan gospodarski pothvat. Ugovorom se može urediti i pitanje najvišeg iznosa dobiti na koji ulagač ima pravo - tu je riječ o vezivanju maksimalnog iznosa netto dobiti za ekonomske pokazatelje u toj gospodarskoj grani. Jedan od kriterija za izmjenu odredaba može biti i isplativost ulaganja s posebnim osvrtom na položaj ulagača u tržišnom natjecanju. Promjena ugovora može se vezati i za standarde koje propiše neka međunarodna organizacija ili strukovna udruženja u konkretnoj gospodarskoj grani. Četvrto, ugovorom treba urediti i sam postupak ponovnog pregovaranja te posebice urediti mehanizme za slučaj ako strane ne postignu dogovor, npr. ugovaranjem arbitraže ili formiranjem posebnog odbora za ponovno pregovaranje. ${ }^{19}$ Što su kriteriji preciznije razrađeni, veća je spremnost ugovornih strana na suradnju i kompromis jer su svjesne mogućih negativnih učinaka koji proizlaze iz povrede ugovora, a i ti učinci će njime također biti detaljno uređeni. Ako se razrade sve pretpostavke, tada je zapravo riječ o ugovoru koji sadrži klauzulu o automatskoj izmjeni pojedinih odredaba. Takva klauzula predstavlja rješenje za slučajeve promijenjenih okolnosti, ali ne smije se zaboraviti činjenica da je i spomenuta klauzula ugrađena u ugovor onda kada je inozemni ulagač imao jaču pregovaračku poziciju. Ako takav ugovor predviđa postupno jačanje pravnog položaja države kao ugovorne strane kroz rast postotka njezinog sudjelovanja u dobiti pothvata iskorištavanja ugljikovodika, tada se smanjuju napetosti između ugovornih strana. Ipak, ako je pravni položaj ugovornih strana od početka izrazito neravnopravan, takva odredba će samo u manjoj mjeri ublažiti to stanje. S tim u svezi, treba ispitati ima li načelo vladavine prava ikakav značaj u odnosima ulagača i države domaćina kada je riječ o pravnom poslu iskorištavanja ugljikovodika. ${ }^{20}$ Načelo vladavine prava u svezi s pravima ulagača prema državi ostvaruje se ako ugovor između ulagača i države domaćina sadrži stabilizacijsku klauzulu, odgovarajuća jamstva za ulagača te odredbe o nadležnosti međunarodnog arbitražnog tijela za slučaj spora. Temelj načela vladavine prava jest da učinci pravnih pravila moraju biti predvidivi te da treba poštovati stečena prava. Ipak, ne vrijedi zaključak da svaka jednostrana izmjena predstavlja povredu ugovora, ali takvo postupanje stvara oborivu pretpostavku da je nastupila ta posljedica. Do povrede ugovora najčešće će doći ako se želi

19 Vidi Bantekas, I.; Paterson, J.; Suleimanov, M., Oil and Gas Law in Kazakhstan: National and International Perspectives, Kluwer Law International, 2004., str. 16. i dalje.

20 Tamanaha, B., On The Rule of Law: History, Politics, Theory, Cambridge University Press, 2004., str. 127-137;Usp. Bačić, A., Hrvatska i izazovi konstitucionalizma, Književni krug, Split, 2001., str. 88. 
jednostrano izmijeniti odredbu koja je zaštićena stabilizacijskom klauzulom, ali i onda kada izmjena utječe na „opravdana očekivanja“ druge ugovorne strane. Ipak, čak i kod fiskalnih izmjena ne mora nužno biti riječi o povredi ugovora. Većina razvijenih država redovito usklađuje porezne i regulatorne odredbe. U tom postupku uzima se u obzir relativna profitabilnost te grane gospodarstva, ali i drugi čimbenici. Država želi i dalje zadržati interes ulagača te ih poticati da ulažu u skupe i rizične istraživačke pothvate (npr. pothvati u Sjevernom moru). Ulagači su svjesni da se odredbe ugovora moraju uskladiti, ali oni očekuju da će se fiskalni i regulatorni režimi usklađivati u duhu načela ravnopravnosti ugovornih strana. Ulagači neprestano procjenjuju omjer političkog, fiskalnog i regulatornog rizika u odnosu s očekivanom, predvidivom dobiti i drugim koristima koje bi mogli ostvariti upuste li se u takav gospodarski pothvat.

Pravna sredstva za zaštitu ulaganja koristit će se u većoj mjeri u onim državama u kojima je prisutna relativna politička nestabilnost (Rusija, Venezuela, Bolivija). ${ }^{21}$ Ulagači će tražiti i druge načine da zaštite svoja ulaganja pa je nerijetko slučaj da se povežu s političkim moćnicima u tim državama na način da im besplatno prenesu udjele u zamjenu za političku zaštitu ili da se služe drugim oblicima korupcije. Pokazalo se, nažalost, da niti opisani trodijelni sustav zaštite ulaganja (nacionalno pravo, ugovorni mehanizmi, međunarodna arbitraža temeljena na konvencijama koje uređuju to područje) ne pruža punu i sveobuhvatnu zaštitu ulagačima. Vladavina prava u tim državama vrijedi samo na papiru jer su u stvarnosti svi postupci i institucije koje ih provode (sudovi, tužitelji, pravosudni sustav, policija, porezna uprava) pod punom i izravnom kontrolom onih koji imaju političku moć nad državnim sustavom. ${ }^{22}$

\section{ODREDBE ZA AUTOMATSKU IZMJENU UGOVORA}

Ako ugovor sadrži odredbu o automatskoj izmjeni pojedinih odredaba, tu će redovito biti riječi o sljedećim pitanjima: politika zapošljavanja, gospodarski razvoj države domaćina, prostorni obuhvat, fiskalni režim ugovora (porezi, koncesijska naknada te razne druge naknade), podjela dobiti između ugovornih strana (reinvestiranje, pravo na stjecanje novih udjela - dionica, postupno gašenje proizvodnje). U nastavku se raspravlja o tim pitanjima.

Prvo, ugovorom se moraju urediti dostatno dinamične, promjenjive odredbe

21 Stodder, S.; Orr, R. J., „Understanding Renegotiation and Dispute Resolution Experience in Foreign Infrastructure Investment - Proceedings of the 2nd General Counsels' Roundtable February 1011, 2006“, Journal of World Investment \& Trade, Vol. 7, 5 (2006.), str. 805. i dalje.

22 U praksi se, naime, pokazalo da se nabrojenim pravnim sredstvima postiže samo privid o postojanju pravne zaštite. Države bogate prirodnim resursima ne primjenjuju načelo vladavine prava već provode, prema riječima ruskog predsjednika Putina, ,diktaturu prava“. Drugim riječima, one pravo primjenjuju selektivno kako bi osigurale da su sva prava koja inače pripadaju ulagaču izložena proizvoljnom postupanju onih koji kontroliraju formalne i neformalne izvore moći (poluge moći). Detaljnije vidi u prikazu knjige kod Andrew-Speed, P., ,International Competition for Resources: the Role of the law, the State and of Markets“, Journal of Energy \& Natural Resources Law, Vol. 27, 1 (2009.), str. 106. i dalje. Također vidi i Ledeneva, A., How Russia Really Works - The Informal Practices That Shaped Post-Soviet Politics and Business, Cornell, 2006., str. 164-168. 
o podjeli dobiti. Treba prilagoditi odredbe o naknadama za korištenje nalazišta. Iznos naknade može se stupnjevati tako da bude poticaj proizvodnji. Ta naknada određuje se tako da ima fiksni i varijabilni dio pri čemu je varijabilni dio vezan uz cijenu proizvoda na svjetskom tržištu, tako da i država domaćin preuzme dio rizika pothvata, ali uz mogućnost ostvarenja povećanog iznosa dobiti. Nadalje, porezna stopa se najčešće ugovara tako da ona raste nakon što se ostvario naznačeni iznos ukupne dobiti, nakon što su se ulagaču vratila početna ulaganja te nakon proteka ugovorenog roka. Potrebna mjera prilagodljivosti mora biti ostvarena i u knjigovodstvenoj sferi. Tako se u početnom proizvodnom ciklusu, do povrata uloženih sredstava, provodi ubrzana amortizacija opreme što povećava dotok novca u društvo. Sličan učinak ostvaruje se i prenošenjem gubitka na sljedeće fiskalno razdoblje. S vremenom se te povlastice postupno dokidaju, a zakupnina raste kako bi se potaklo ulagača da koncesionirano područje prepusti državi domaćinu. Postupno po visini pada i iznos naknade za usluge tehničkog upravljanja pothvatom, koju država domaćin ili društvo osnovano za potrebe poduzetničkog pothvata plaćaju ulagaču. Time se potiče ulagača da za te poslove što prije osposobi domaću radnu snagu. Također, može se ugovoriti i postupno povećanje udjela države u dobiti mehanizma sudjelovanja u dobiti.

Drugo, u pogledu zapošljavanja, ugovorom se može razraditi vremenski slijed provedbe postupka stručnog usavršavanja domaćih zaposlenika i rok u kojem će domaći zaposlenici dobiti upravljačke - menadžerske položaje u tom trgovačkom društvu.

Treće, ugovorom se može urediti i pitanje sužavanja područja eksploatacije. Riječ je o odredbi koja se povezuje prvenstveno s iskorištavanjem ugljikovodika, a sastoji se u postupnom sužavanju, napuštanju područja dijelova područja obuhvaćenih koncesijom za iskorištavanje ugljikovodika. Nakon svake faze (ispitivanje, istraživanje, iskorištavanje) ili nakon određenog vremenskog razdoblja, ulagač mora napustiti određeni postotak ukupne površine područja iskorištavanja. Tom mjerom potiče se ulagača na povećanu aktivnost istraživanja i iskorištavanja. Time se želi spriječiti da ulagač „zauzme“ područje samo da bi spriječio konkurente, a s druge strane otvara se mogućnost da država nastavi samostalno iskorištavati ostatak zaliha na područjima koje ulagač napušta. Druga mogućnost s tim u svezi je odredba prema kojoj se jedan dio nalazišta mora sačuvati kao nacionalna rezerva koja je od strateškog interesa za tu državu. ${ }^{23}$

Četvrto, ugovor može sadržavati odredbe o postupnom snižavanju iznosa ulaganja, tzv. deinvestiranje (eng. Phase-out, fade-out). ${ }^{24} \mathrm{Tu}$ je zapravo riječ o ugovorom uređenom postupku nacionalizacije gospodarskog pothvata tj. o ponovnom stjecanju suverenih prava države domaćina. Deinvestiranje označava proces u kojem ulagačko društvo počinje kao većinski dioničar/udjeličar u pothvatu. Prema unaprijed uređenom vremenskom periodu i rasporedu, država domaćin preuzima udjele te stječe upravljačka prava u trgovačkom

${ }^{23}$ Calle, L. F.; Alberro, J. L.; Starr, P., Oil as a strategic resource in Mexico?, Woodrow Wilson Center, Mexico Institute, 2007., str. 5.

24 Bindemann, K., Production-Sharing Agreements: An Economic Analysis, Oxford Institute for Energy Studies, WPM 25, 1999., str. 13. 
društvu - nositelju gospodarskog pothvata. ${ }^{25}$ Deinvestiranje je slično postupku nacionalizacije jer ulagač pristaje na postupnu nacionalizaciju pod unaprijed razrađenim pretpostavkama posebice u svezi s iznosom naknade koju država isplaćuje ulagaču. S polazišta države domaćina, to je mirno sredstvo za ponovnu uspostavu suverenih prava nad resursima, a taj postupak provodi se paralelno s procesom učenja, uvježbavanja, tako da država bude spremna u budućnosti samostalno upravljati pothvatom iskorištavanja ugljikovodika. To je jedan od glavnih razloga zbog kojih veliki broj nacionalnih propisa o stranim ulaganjima predviđa posebne olakšice za provedbu postupnog deinvestiranja. Međutim, ugovori o iskorištavanju ugljikovodika često ne sadrže odredbe o deinvestiranju jer to ne odgovara interesima ulagača. Tako se u praksi pokazalo da niti porezne olakšice nisu dostatni poticaj da bi ulagač pristao na deinvestiranje. Stoga je bolje pitanje deinvestiranja detaljno urediti ugovorom. ${ }^{26}$

Valja razlikovati slučaj deinvestiranja, koje za posljedicu ima da država domaćin stječe pravo (manjinskog) sudjelovanja u pothvatu, od slučaja kada država postaje jedini ili većinski član pothvata. Ono se može provesti tako što će se dionice ponuditi vladi ili državnom trgovačkom društvu koje se bavi tim poslovima te eventualno državljanima. Ugovorom se može razraditi u kojem trenutku, pod kojim pretpostavkama država može iskoristiti pravo opcije što vladi države daje jaku pregovaračku poziciju. U suvremenim ugovorima o iskorištavanju ugljikovodika, država domaćin često dopušta ulagaču da na vlastiti rizik i trošak provede istraživanje pod uvjetom da država pridrži pravo opcije kupnje dijela dionica/udjela (manjinski, većinski dio ili sve) nakon što je provedeno istraživanje i izrađena studija isplativosti. Pravo opcije može biti ugovoreno pod unaprijed određenoj, nižoj cijeni. Protuteža toj povlastici najčešće se sastoji u tome da se finalni proizvod smije prodavati samo ulagaču ili primjerice u tome da on ugovorenu cijenu plaća obročno, a mogu se ugovoriti i druge povlastice, primjerice da pravo naplatnog pružanja usluga tehničkog vođenja projekta pripada isključivo ulagaču i sl. Pokazalo se da je ulagačima najvažnije pothvatom osigurati stabilnu, konstantnu opskrbu klijenata energentima što je cilj koji ima prednost pred brzom zaradom. ${ }^{27}$

Značajno je i pitanje hoće li se deinvestiranje provesti povećanjem temeljnog kapitala ili prijenosom dijela ulagačevih dionica/udjela na državu. Tada se dodatno postavlja pitanje vrijednosti dionice društva - nositelja pothvata. Taj se iznos kreće u rasponu od tržišne cijene, povišene cijene ili knjigovodstvene vrijednosti. Važno je i pitanje isplaćuje li se cijena odmah ili, što nije rijetkost, iz dobiti ostvarene proizvodnjom pri čemu nije isključena mogućnost da zbog isplate država izda obveznice. Kriteriji i metode za utvrđivanje vrijednosti dionice/udjela mogu biti

25 To vrijedi u onim slučajevima kada je za potrebe ostvarenja ciljeva pothvata osnovano trgovačko društvo.

26 Johnson, W.; Messick, R., „Vertical Divestiture of U.S. Oil Firms“, Law and policy in international business: the international journal of Georgetown University Law Center, Vol. 8, 4 (1976.), str. 963-989.

27 Frilet, M.; Haddow, K., „Guiding Principles for Durable Mining Agreements in Large Mining Projects“, Journal of Energy \& Natural 468 Resources Law, Vol. 31, 4 (2013.), str. 467. 
utvrđeni ugovorom. Međutim, država domaćin ponekad će namjerno propusti urediti to pitanje kako bi imala bolju pregovaračku poziciju. Kriterij utvrđivanja vrijednosti dionice koji je utvrđen u izvornom ugovoru redovito ide u korist ulagača koji ima bolju pregovaračku poziciju. Upravo suprotan je slučaj kada se vrijednost utvrđuje kod pregovora o deinvestiranju. Tada države ugovornice nastoje da jedini kriterij određivanja vrijednosti bude samo knjigovodstvena vrijednost društva - nositelja pothvata.

Nesporno je da postupak deinvestiranja ima brojne pozitivne značajke jer je riječ o relativno pouzdanom i „,mirnom“ sredstvu kojim se ostvaruje prilagodljivost ugovora, a time i postupno ostvarenje cilja punog suvereniteta nad resursima. Ipak, treba se očitovati i o negativnim stranama tog postupka. Prvo, treba uzeti u obzir cijenu (trošak) deinvestiranja. Vlada države dvaput će razmisliti prije nego što će najčešće oskudna državna sredstva uporabiti za kupnju dionica/udjela u društvu nositelju pothvata, posebice ako se državi nude udjeli u fazi kada je nalazište praktički iscrpljeno. Drugi prigovor postupku deinvestiranja jest plan da država postupno stekne većinsko pravo odlučivanja te upravljačka prava. Naime, taj cilj može se ostvariti i drugim pravnim sredstvima kao što je ugovorom predviđeno pravo države da imenuje svoje predstavnike u upravni/nadzorni odbor i/ili na funkciju člana uprave - direktora. Uostalom, znanost i praksa iz područja prava društava jasno razlikuju pojam većine glasova od pojma većinskog prava odlučivanja u društvu što znači da postoji mnogo načina kojima se može urediti to pitanje. ${ }^{28}$

Nadalje, za državu nije od presudnog značaja da temeljem udjela sudjeluje u dobiti jer se slični učinci mogu ostvariti sustavom poreza i drugih nameta. Zamišljeni cilj ovladavanja projektom često se, usprkos provedbi deinvestiranja, ne može ostvariti jer ulagač najčešće pridržava pravo da preko menadžerskih ugovora i dalje ima moć odlučivanja u društvu nastalom za potrebe ostvarenja pothvata. Već se ranije navelo da otjecanje kapitala kroz deinvestiranje nema smisla ako država nema sredstava da sama uloži u pothvat. Ako država nema

razvijeno tržište kapitala (burzu), deinvestiranje u okviru kojega se dionice nude na prodaju građanima nema nikakvog smisla. ${ }^{29}$

Ipak, deinvestiranje ne treba potpuno napustiti kao sredstvo: taj postupak može u kombinaciji s drugim mjerama postupno ojačati pravni položaj države u pothvatu. Ipak treba pažljivo razmotriti pitanje cijene deinvestiranja, omjere sudjelovanja javnog i privatnog partnera, učinke partnerstva s motrišta nacionalnog suvereniteta nad prirodnim resursima. Deinvestiranje treba vrednovati i koristiti

${ }_{28}$ To je pitanje posebno vidljivo kod povezanih društava. O tome detaljnije Barbić, J., Pravo društava, Opći dio, Organizator, Zagreb, 2006., str. 615. i dalje.

29 Posebice se kod takvih postupaka u jugoistočnoj Aziji pokazalo da je domaći stjecatelj praktički ulagačev povjerenik: ulagač i dalje kontrolira cijeli pothvat. Lokalni partner u pravilu služi samo da se osigura politička podrška pothvatu koji će se provesti u obliku javno-privatnog partnerstva. Detaljnije o tome Weinstein, F., „Multinational Corporations and the Third World: The case of Japan and South East Asia“, Int’l Organization, Vol. 30, 6 (1976.), str. 373-404. 
zajedno s drugim pravnim sredstvima koja stoje na raspolaganju ugovornim stranama.

\subsection{Klauzula najpovoljnije odredbe}

Još jedno sredstvo izmjene ugovora jest uvođenje pravila (klauzule) o primjeni tzv. najpovoljnije odredbe. Ono se sastoji u tome da se ugovorne strane međusobno obvezuju ponuditi povoljnije uvjete onda kada takve uvjete nude trećima, tj. kada s trećima sklope istovrsne ugovore pod povoljnijim uvjetima od onih pod kojima je sklopljen ugovor o iskorištavanju ugljikovodika. Tu je prvenstveno riječ o povoljnijim fiskalnim odredbama, odredbama o strukturi cijena, metodama proizvodnje, marketingu i razvoju područja proizvodnje. Svaka od ugovornih strana može zahtijevati da se i njoj ponude povoljniji uvjeti kakve druga strana nudi trećima - novim poslovnim partnerima. Spomenuta klauzula nastala je u poslovnoj praksi u svezi s primjenom međunarodnih trgovačkih konvencija. Davanje boljih uvjeta u kasnijem sporazumu drugoj ugovornoj strani prvog (izvornog) ugovora može se provesti automatski ili se može ugovoriti da je to važna pretpostavka za ponovo pregovaranje. Klauzula „,najpovoljnije odredbe“ često se koristi u koncesijskim ugovorima. ${ }^{30}$ Time je ulagač, nerijetko jednostrano, pridržao pravo izmjene pojedinih ugovornih odredaba u svoju korist. Takve su klauzule izložene kritici. Naime, tom klauzulom ograničava se pregovaračka snaga države ugovornice u novim pregovorima, a teško ih je i primijeniti jer nije jednostavno izdvojiti samo jednu odredbu koja je „povoljnija“ za treće koji su naknadno sklopili ugovor, već treba promatrati ugovor kao cjelinu jer je možda druga strana zbog te odredbe tijekom pregovora dala neki drugi ustupak. U ugovorima o iskorištavanju ugljikovodika ta se klauzula često primjenjuje, ali je pomalo neočekivano da se razvija u području najpovoljnijih odredaba za državu domaćina, na način da se država domaćin poziva na to da je primjerice susjedna država s istim ulagačem sklopila ugovor koji sadrži za državu povoljnije uvjete. ${ }^{31}$ Prednost ovog pristupa jest da je u prvobitni ugovor ugrađena ta odredba pa se time stvaraju pretpostavke za pregovore. Time se otklonila opasnost da jedna od ugovornih strana (najčešće država ugovornica) različitim pseudopravnim sredstvima „prisiljava“ drugu stranu na izmjenu pojedinih odredaba ugovora. ${ }^{32}$ Zanimljivo „srednje rješenje“ jest da početni ugovor bude kraćeg trajanja $(5$ g.) a da sadrži pravo ulagača na produljenje ugovora, ali samo ako ulagač prihvati izmjene ugovora koje će odgovarati konkretnim okolnostima. Procjena konkretnih okolnosti vezuje se za bitno slične ugovore koje naftna trgovačka društva sklapaju

30 Cole, T., „The Boundaries of Most Favored Nation Treatment in International Investment Law“, Mich. J. Int'l L., Vol. 33, 3 (2012.), str. 537.

31 Usp. Considine, T., Natural gas pricing policies: implications for the federal budget, United States, Congressional Budget Office, 1983., str. 13.

32 Čest je slučaj da vlada države ugovornice sazna podatak da je susjedna država sklopila istovrsni ugovor s istim ulagačem pod povoljnijim uvjetima pa tada različitim mjerama želi prisiliti ulagača da pristane na izmjenu odredaba njihovog ugovora u smislu da se uskladi sa sadržajem ugovora koji je ulagač naknadno sklopio s drugom državom. 
s državama domaćinima. Rješenje prema kojem se prvobitni ugovor sklapa na kraće vrijeme a isti se može produljiti uz dužnost izmjene prema okolnostima koje tada vladaju na tržištu, čini se razumnim postupanjem kojim će se izbjeći nepotrebni sporovi uzmeđu ugovornih strana. ${ }^{33}$

\subsection{Pitanje više sile te ostale odredbe ugovora o iskorištavanju ugljikovodika}

Postoji veći broj različitih ugovornih odredaba tj. pravnih sredstava kojima se ostvaruje cilj veće prilagodljivosti ugovora novim okolnostima. Uporaba tih pravnih sredstava ukazuje na trend posvećivanja sve veće pozornosti zaštiti suverenih prava države domaćina. Posebice je detaljno razrađena odredba o višoj sili. U suvremenim ugovorima o iskorištavanju ugljikovodika vodi se računa o tome da ne može baš svaki događaj koji bi po definiciji spadao u višu silu za posljedicu imati nastanak pravnih učinaka koji uobičajeno proizlaze iz okolnosti da neki događaj predstavlja višu silu. Pokaže li se da taj događaj presudno utječe na pravni odnos, tada ugovorne strane nisu ovlaštene primjerice na raskid ugovora već ponovno moraju sjesti za pregovarački stol. Takva klauzula onda ima za posljedicu ponovno pregovaranje ako je nastupio događaj koji predstavlja višu silu jer je poremećena ravnoteža između ugovaratelja. ${ }^{34}$

Nadalje, ti ugovori nerijetko sadrže i odredbu o pravu ustupa (cesiji) tražbine te o pravu prijenosa ugovora (pravne pozicije ulagača) kao cjeline. Ulagač slobodno može raspolagati tim pravima, ali u novije vrijeme ipak se to pravo prijenosa ugovora ograničava i uvjetuje pristankom druge ugovorne strane (države) barem kroz formulaciju da država može staviti veto na prijenos tražbine ako postoji važan razlog. U tim ugovorima česta je odredba da u slučaju kada ulagač iskaže namjeru prijenosa svog udjela na treće, pravo prvenstva kod stjecanja ima država ugovornica (ili trgovačko društvo čiji je većinski član država) ili se unosi odredba da je moguć prijenos prava samo na subjekte koji imaju sjedište u državi ugovornici. ${ }^{35}$ Država ugovornica dopustit će primjenu spomenutih pravnih instrumenata kada je vidljivo da treba uključiti nove ulagače zbog opskrbe pothvata dodatnim kapitalom. ${ }^{36} \mathrm{U}$ svakom slučaju, sve poviše spomenute okolnosti mogu predstavljati važan razlog za ponovno pregovaranje.

Isto vrijedi i za klauzulu o izmjeni ugovora prema stanju na konkretnom tržištu. Uspije li država ugovornica nametnuti odredbu o izmjeni ugovora prema trenutnim okolnostima i uvjetima koji vladaju na tržištu, ta odredba postat će

33 Schefer, K. N., International Investment Law: Text, Cases and Materials, Edward Elgar Publishing, 2013., str. 292.

34 Swanson, J., ,The hand of God: limiting the impact of the force majeure clauses in oil and gas lease“, North Dakota Law Review, Vol. 89, 2 (2013.), str. 227. i dalje.

35 U posljednje navedenom slučaju želi se postići da se na stjecatelja u potpunosti primjenjuje pravo države ugovornice.

36 Primjerice, ako je za potrebe ostvarenja pothvata nastao konzorcij, njegovi članovi (ulagač i država) sporazumno mogu odlučiti o primanju novog člana (novog ulagača) koji će uložiti dodatna sredstva za financiranje pothvata. 
moćno pravno sredstvo, posebice ako je riječ o ugovoru sklopljenom na kraće razdoblje. ${ }^{37}$

Ugovorne strane imaju i pravo na raskid ugovora ako druga strana krši svoje ugovorne obveze ili se ispune druge ugovorom precizno određene pretpostavke. ${ }^{38}$ Pravo na raskid po samoj prirodi stvari ne predstavlja sredstvo za izmjenu ugovora, ali ono neizravno doprinosi ostvarenju tog cilja. Njime se upozorava u prvom redu ulagača da poštuje svoje ugovorne obveze i te odredbe u pravilu jačaju pravni položaj države ugovornice. Odredbe o pravu na raskid detaljno su razrađene zbog ozbiljnih pravnih učinaka koje imaju. Ugovorne strane ih moraju prilagoditi konkretnim okolnostima koje mogu nastati u svezi s pothvatom iskorištavanja ugljikovodika.

Razdioba troškova i koristi između ulagača i države domaćina u najvećoj mjeri ovisi o tome kada su obavljeni završni pregovori i sklopljen ugovor. Ako se o ugovoru pregovara prije faze ispitivanja i/ili istraživanja, ulagač će u pravilu imati bolji pregovarački položaj. Pokaže li se pothvat isplativim, država domaćin će zahtijevati da se pojedine odredbe ugovora izmijene tj. pokrenut će nove pregovore. Da bi se osigurala stabilnost ugovora, najbolje je rješenje da se završni pregovori održavaju onda kada je već znatno smanjen rizik od neuspjeha pothvata. To se ispunilo posebice kada su okončane rizične i skupe faze ispitivanja $i$ istraživanja ležišta. Također će se znatno smanjiti rizik ponovnog pregovaranja onda kada je izrađena studija isplativosti pa su poznate sve tehničke i ekonomske značajke pothvata. ${ }^{39}$

Međutim, sklopi li se ugovor tek tada, ulagač gubi interes jer ako ugovorom ne stekne povlastice, neće se ni upuštati u rizične i skupe aktivnosti koje prethode proizvodnji (ispitivanje i istraživanje). Ravnoteža interesa nastoji se ostvariti na različite načine. Jedna je mogućnost da ulagač provede radnje ispitivanja i istraživanja temeljem samostalnog ugovora o istraživanju kojim se ne uređuju pitanja proizvodnje. U ovoj fazi ulagač očekuje od države domaćina da se obveže na naknadu troškova bez obzira na ishod. Može se ugovoriti da ulagač stječe pravo prvenstva kod pregovora o proizvodnji, pravo na posebnu nagradu (premiju) za uspješno provedeno istraživanje ili da mu se pruži neka druga povlastica financijske prirode. Također, moguće je da ugovor o istraživačkom pothvatu uredi samo osnovna pitanja budućeg ugovora o proizvodnji koji bi se trebao sklopiti nakon provedenog istraživanja. Primjerice, tim ugovorom može se predvidjeti željeni/ciljani omjer povrata uloženog te se mogu navesti barem temeljni sastojci ugovora o iskorištavanju ugljikovodika koji će se sklopiti nakon izrade studije isplativosti. Nadalje, na sadržaj ugovora utječu i ciljevi koje njime država domaćin želi ostvariti: nerijetko državi domaćinu nije bitna dobit već se građanima i trgovcima želi osigurati dugogodišnja, kontinuirana i stabilna opskrba

37 S takvim ugovorima su izjednačeni slučajevi kada je ugovor sklopljen, doduše, na dulji rok ali sadrži odredbu da se, primjerice, nakon pet godina od sklapanja mora ponovno pregovarati.

38 Npr. pokaže li se nakon nekog vremena da pothvat ne donosi dobit već naprotiv nastaju gubici.

39 Moran, T. H., Investing in Development: New Roles for Private Capital?, Transaction Publishers, 1986., str. 81. i 101. 
tim energentom..$^{40}$ Uočava se trend da se pregovori o najvažnijim odredbama budućeg ugovora o proizvodnji ostavljaju za razdoblje nakon istraživačke faze.

Treba spomenuti još jednu skupinu pravnih sredstava kojima se može koristiti država domaćin. Već je bilo riječi o tome da izmjene zakona predstavljaju „neizravan“ način jednostrane izmjene ugovora, ali ne smije se zaboraviti niti to da se taj učinak ostvaruje i primjenom različitih administrativnih (upravnih) mjera koje se ugrađuju u propise o inozemnim ulaganjima. Jedna od tih mjera jest da se posebnom tijelu, ulagačkom odboru, dodijeli pravo (ovlast) da svakih 3 do 5 godina posebno odobri nastavak pothvata. Stoga, iako je riječ o višegodišnjem ugovoru, pothvat se neće nastaviti ako spomenuti odbor tako odluči. Time se tom tijelu daje posebna ovlast da zahtijeva izmjenu ugovora kada to zahtijevaju okolnosti konkretnog slučaja.

\subsection{Značajke novijih sporova u svezi s inozemnim ulaganjima}

Sporovi o poduzetničkim pothvatima vezani su uz proces dubljih političkih promjena u državi ugovornici. Ako je ugovor sklopila vlada sačinjena od članova i koalicijskih partnera jedne stranke, nova vlada koju je sastavila druga stranka pokušat će ga izmijeniti. Rijetko će biti slučaj da spor iz ugovora vodi vlada koja ga je sklopila. To će se izuzetno dogoditi samo onda ako dođe do osobnih sukoba, pojedinačnih slučajeva korupcije ili do ozbiljnih promjena okolnosti u svezi s ulaganjem. „Normalan“, uobičajeni slučaj spora u svezi s inozemnim ulaganjem u pothvat jest da nova vlada stavlja izvan snage ili mijenja odredbe ugovora koje su bile zaštićene stabilizacijskom klauzulom. Međunarodno pravo (pa niti jedno nacionalno) ne priznaje okolnost promjene vlade kao važan razlog za prestanak obveza iz ugovora. Vlada djeluje u ime i za račun države pa je država vezana tako preuzetim obvezama ${ }^{41}$ Ipak, nerijetko će investitori snositi posljedice političke naravi zbog bliskosti s prethodnom vladom. Rizik promjene režima utoliko je veći ako nova vlada ima drugačija polazišta prema privatnim inozemnim ulaganjima u resurse koji imaju strateški značaj: ugljikovodici, energetika, rudarstvo, infrastruktura i telekomunikacije. ${ }^{42}$ Što je strateški interes pojedine države, opet je političko pitanje. ${ }^{43}$ Ponekad su te izmjene kozmetičke naravi. Vještina

40 Beredjick, N., Petroleum Investment Policies in Developing Countries, Springer, 1988., str. 91.

${ }^{41}$ U znanosti i praksi raspravlja se o polazištu da ,nijedna vlada ne može obvezati svoje sljednike“. Zasigurno je riječ o pitanju koje može uzrokovati pravnu nesigurnost pa razvijene države izražavaju skepsu prema primjeni tog polazišta. Detaljnije o tome vidi De Vries, P.; Yehoue, E., The Routledge Companion to Public-private Partnerships, Routledge, 2013., str. 238.

42 Stabilizacija ugovora može se ostvariti tzv. kišobran klauzulom tj. zaštitom pojedinih odredaba ili cijelog ugovora na način da se na ugovor primjenjuju pravila međunarodnog prava, a za slučaj spora ugovara se nadležnost međunarodnog arbitražnog sudišta. O tome detaljnije vidi Wälde, T. H., „The umbrella clause in investment arbitration a comment on original intentions and recent cases", Journal of World Investment \& Trade, Vol. 6, 2 (2005.), str. 183-236.

43 Što se smatra strateškim interesom nije znanstveno niti ekonomsko već političko pitanje. Tako je francuska vlada označila proizvodnju jogurta strateškim pitanjem kada je postojala opasnost preuzimanja francuskog trgovačkog društva Danone. Kraljevina Švedska je svojevremeno proglasila proizvodnju cipela za djelatnost od strateškog interesa. Vidi Hahn, M., ,Vital interests and the law of GATT: An analysis of GATT's security exception“, Michigan Journal of International Law, Vol. 12, 3 (1991.), str. 
pregovaranja jest u tome da obje strane budu zadovoljne na način da će ulagač na neizravan način sačuvati svoja prava, s obzirom na uložena sredstva, a vladi države će se zbog birača omogućiti privid da je ona u pravom smislu riječi nositelj suverenih prava nad vrijednim prirodnim izvorima energije.

\section{ZAKLJUČAK}

Kod ugovora o iskorištavanju ugljikovodika pokazalo se da veliku pozornost treba posvetiti pregovorima koji mu prethode. Trajnost ugovora najčešće je rezultat okolnosti da su pregovarači imali ravnopravan položaj. Ipak, istraživanje temeljnih pravnih mehanizama, postupka ponovnog pregovaranja te različitih pravnih sredstava koja se koriste kod takvih ugovora ukazuje na zaključak da se takvi ugovori neprestano moraju prilagođavati. Stoga je nužno u te ugovore ugraditi odredbe koje uređuju postupak njihove „,bezbolne“ izmjene, prilagodbe novim okolnostima kako bi svim sudionicima unaprijed bila jasna „pravila igre“. Ako se ta pitanja detaljno urede, manja je mogućnost nastanka skupih i dugotrajnih sporova. Kod pregovaranja treba uzeti u obzir sve okolnosti konkretnog slučaja te pronaći pravu mjeru u korištenju svih poviše opisanih pravnih sredstava kako bi se ostvario osnovni cilj - prilagodljivost ugovora novonastalim okolnostima. Posebice treba uzeti u obzir uzročno-posljedičnu vezu između odredaba koje štite interese samo jedne od ugovornih strana s motivacijom druge ugovorne strane. Tu će biti važno riješiti fiskalna pitanja, očekivane ekonomske rezultate proizvodnje, mehanizam rješavanja sporova kao i pitanje financiranja projekta. U radu se pokazalo da ni jedno od opisanih rješenja nema apsolutnu prednost nad ostalima već se najbolji rezultati ostvaruju s(p)retnim kombiniranjem većeg broja tih pravnih sredstava. Konačni cilj bio bi da države domaćini s vremenom ostvare puni opseg suverenih prava nad svojim prirodnim energetskim resursima. To je za mnoge države koje su i inače opterećene gospodarskim poteškoćama teško dostižan cilj jer strani ulagači u velikom broju slučajeva nastavljaju voditi „glavnu riječ“ čak i onda kada država domaćin ima većinske udjele/dionice u društvu nastalom radi provođenja zajedničkog pothvata. To će primjerice biti slučaj ako je i dalje na snazi ugovor o upravljanju projektom te drugi ugovori o uslugama kod kojih ulagač za visoku naknadu (ili za pravo prvokupa dijela proizvodnje po fiksnoj, nižoj cijeni) nastavlja pružati tehničku podršku radi boljih rezultata pothvata.

558-620. Vlada SAD-a široko shvaća pojam strateškog interesa - tu spada i suvremena proizvodnja elektroničkih uređaja, gospodarenje pomorskim i zračnim lukama. Tako je 2007. godine spriječeno kinesko neprijateljsko preuzimanje američkog naftnog trgovačkog društva kao i preuzimanje jedne američke luke (trgovačkog društva) zajedno s njezinom infrastrukturom. Alvarez, J., „Political Protectionism and United States International Investment Obligations in Conflict: The Hazards of Exon-Florio“, Virginia Journal of International Law, Vol. 30, 1 (1989.), str. 171. 


\section{Literatura:}

1. Alvarez, J., „Political Protectionism and United States International Investment Obligations in Conflict: The Hazards of Exon-Florio“, Virginia Journal of International Law, Vol. 30, 1 (1989.), str. 1. i dalje.

2. Andrew-Speed, P., „International Competition for Resources: the Role of the law, the State and of Markets", Journal of Energy \& Natural Resources Law, Vol. 27, 1 (2009.), str. 104. i dalje.

3. Bačić, A., Hrvatska i izazovi konstitucionalizma, Književni krug, Split, 2001.

4. Bantekas, I.; Paterson, J.; Suleimanov, M., Oil and Gas Law in Kazakhstan: National and International Perspectives, Kluwer Law International, 2004., str. 16. i dalje.

5. Barbić, J., Pravo društava, Opći dio, Organizator, Zagreb, 2006.

6. Beredjick , N., Petroleum Investment Policies in Developing Countries, Springer, 1988.

7. Bindemann, K., Production-Sharing Agreements: An Economic Analysis, Oxford Institute for Energy Studies, WPM 25, 1999.

8. Böckstiegel, K., Der Staat als Vertragspartner Ausländischer Privatunternehmen, Athenäum-Verlag, Frankfurt a.M./ Bonn, 1971.

9. Calle, L. F.; Alberro, J. L.; Starr, P., Oil as a strategic resource in Mexico?, Woodrow Wilson Center, Mexico Institute, 2007.

10. Cantegreil, J., „The Audacity of the Texaco/Calasiatic Award: René-Jean Dupuy and the Internationalization of Foreign Investment Law", European Journal of International Law, Vol. 22, 2 (2011.), str. 441. i dalje.

11. Cole, T., ,The Boundaries of Most Favored Nation Treatment in International Investment Law“, Mich. J. Int'l L., Vol. 33, 3 (2012.), str. 537. i dalje.

12. Considine, T., Natural gas pricing policies: implications for the federal budget, United States, Congressional Budget Office, 1983.

13. De Vries, P.; Yehoue, E., The Routledge Companion to Public-private Partnerships, Routledge, 2013.

14. Faruque, A., „Validity and Efficacy of Stabilisation Clauses“, Journal of International Arbitration, Vol. 23, 4 (2006.), str. 317. i dalje.

15. Fischer, P., Die Internationale Konzession, Springer, 1974.

16. Frilet, M.; Haddow, K., „Guiding Principles for Durable Mining Agreements in Large Mining Projects“, Journal of Energy \& Natural 468 Resources Law, Vol. 31, 4 (2013.), str. 467. i dalje.

17. Geiger, R., „The Unilateral Change of Economic Development Agreements“, International and Comparative Law Quarterly, Vol. 23, 1 (1974.), str. 73. i dalje.

18. Girsberger, D., „Fundamental alteration of the contractual equilibrium under hardship exemption“", Jurisprudence, 19, 1 (2012.), str. 121. i dalje.

19. Hahn, M., „Vital interests and the law of GATT: An analysis of GATT's security exception“, Michigan Journal of International Law, Vol. 12, 3 (1991.), str. 558. i dalje.

20. Hawkins, R., „Government Takeovers of U.S. Foreign Affiliates“, Int'l Bus 5 (1975.); str. 3. i dalje. 
21. Humphreys, M., Sachs, J. D., Stiglitz, J. E. (Ur.), Escaping the Resource Curse, Columbia University press, New York, 2007.

22. Johnson, W., Messick, R., „Vertical Divestiture of U.S. Oil Firms, Law and policy in international business", International journal of Georgetown University Law Center, Vol. 8, 4 (1976.), str. 963. i dalje.

23. Ledeneva, A., How Russia Really Works - The Informal Practices That Shaped Post-Soviet Politics and Business, Cornell, 2006.

24. Mato, H. T., ,,The Role of Stability and Renegotiation in Transnational Petroleum Agreements", Journal of Politics and Law, Vol. 5, 1 (2012.), str. 33. i dalje.

25. Moran, T. H., Investing in Development: New Roles for Private Capital?, Transaction Publishers, 1986.

26. Oon, K. C., The Politics of Oil in Indonesia: Foreign Company-Host Government Relations, Cambridge University Press, 1986.

27. Prahalad K., Lieberthal, K., The End of Corporate Imperialism, Harvard Business Review Classics, 2008.

28. Schefer, K. N., International Investment Law: Text, Cases and Materials, Edward Elgar Publishing, 2013.

29. Sornarajah, D. M., The International Law on Foreign Investment, Cambridge, 2004.

30. Stodder, S.; Orr, R. J., „Understanding Renegotiation and Dispute Resolution Experience in Foreign Infrastructure Investment - Proceedings of the 2nd General Counsels' Roundtable February 10-11, 2006“, Journal of World Investment \& Trade, Vol. 7, 5 (2006.), str. 805. i dalje.

31. Swanson, J., ,The hand of God: limiting the impact of the force majeure clauses in oil and gas lease“, North Dakota Law Review, Vol. 89, 2 (2013.), str. 225. i dalje.

32. Tamanaha, B., On The Rule of Law: History, Politics, Theory, Cambridge University Press, 2004., str. 127. i dalje.

33. Vukmir, B., Ugovori o zajedničkim ulaganjima, Informator, Zagreb, 1994.

34. Wälde, T., „Law, contract and reputation in international business: What works?“, Bus. Law Intl., 2 (2002.), str. 190. i dalje.

35. Wälde, T., „Managing the Risk of Sanctions in the Global Oil \& Gas Industry: Corporate Response Under Political, Legal and Commercial Pressures“, Texas International Law Journal, Vol. 36., 1 (2005.), str. 183. i dalje.

36. Wälde,T., ,The umbrella clause in investment arbitration a comment on original intentions and recent cases“, Journal of World Investment \& Trade, Vol. 6, 2 (2005.), str. 183. i dalje.

37. Weinstein, F., „Multinational Corporations and the Third World: The case of Japan and South East Asia“, Int'l Organization, Vol. 30, 6 (1976.), str. 373. i dalje.

38. Wellhausen, R. L., The Shield of Nationality, Cambridge University Press, 2014. 


\section{CHANGES TO CONTRACTUAL TERMS AND THE USE OF HYDROCARBONS}

For the contract on exploitation of hydrocarbons it has been shown that great attention should be paid to the negotiation phase. The durability of the contract is usually a result of the fact that the negotiators had equal bargaining power. However, the study of basic legal mechanisms, of the process of re-negotiation and different remedies that are used in these contracts points to the conclusion that such agreements must constantly be updated. It is therefore necessary for such contracts to incorporate provisions governing the procedure for their "painless" change. These provisions should be adaptable to the new circumstances and "rules of the game" must be clear to the contractors from the outset. If these questions are regulated in detail then there is less possibility of costly and lengthy disputes emerging. When negotiating, the parties should take into account all the circumstances of the case and find the right measure for use of all legal means described above in order to achieve the main goal - flexibility of the contract and its adaptability to the new circumstances. The paper showed that none of the given solutions has the absolute advantage over the others, but the best results are achieved by skillful combining a large number of these legal remedies. The ultimate goal would be that the host state realize the full extent of its sovereign rights over its natural energy resources eventually. It is for many countries that are burdened by economic problems a tall order, because foreign investors in many cases continue to have " the last word " even when the host country holds, for example, a majority of shares in the company.

\section{Key words: Contracts relating to the exploitation of hydrocarbons, Joint venture, Concession, Breach of contract, Negotiations}

